\title{
DA MORTE À PERFORMACE: O A(U)TOR CONTEMPORÂNEO
}

Ane Beatriz dos Santos Duailibe ${ }^{1}$

Resumo: A noção de autor passou por momentos distintos ao longo da história, sendo um dos pontos mais controvertidos dos estudos literários. Na contemporaneidade, vive-se um momento em que o autor é parte fundamental da sua produção ficcional, não como um fim último da obra literária, mas como uma figura do espaço público que possui imagens vinculadas a diferentes esferas comunicativas, construindo discursos que se entrelaçam e expandem os limites do literário. O presente artigo volta-se para construção de um debate teórico acerca dessa categoria. Para tanto, esquematiza-se um percurso que contempla tanto estudos que defendem o apagamento do autor enquanto instância textual - como os postulados de Foucault (2002), Barthes (1989; 2004) e Agamben (2007) - como também aqueles que endossam o seu retorno na cena contemporânea - utilizando como alicerce teórico os estudos de Lejeune (2014), Klinger (2012), Schollhammer (2011), Aguilar e Cámara (2017), Hoisel (2019), dentre outros. Assim, aponta-se para uma performance do escritor contemporâneo, que culmina em um ator com poses e máscaras previamente articuladas.

PALAVRAS-CHAVE: Autor. Performance. Literatura contemporânea.

\section{FROM DEATH TO PERFORMANCE: THE CONTEMPORARY AUTHOR/ACTOR}

ABSTRACT: The concept of author went through distinct moments throughout history. In contemporary times we live a moment where the author is a fundamental part of his fictional work, not as the ultimate end of the literary work, but as a figure of the public space that have different communicative spheres which build speeches that intertwine and expand the limits of the literary. This arcticle focuses on the construction of a theoretical debate about this category. To fulfill this objective outlines a path that includes studies that defend the deletion of the author - such as those postulated by Foucault (2002), Barthes (1989; 2004) and Agamben (2007)- as well as those who endorse his return on the contemporary scene- using Lejeune's (2014), Klinger's (2012), Schollhammer's (2011), Aguillar and Camara's (2017), Hoisel's (2019) theoretical studies, among others. Thus, it points to a performance of the contemporary writer culminating with an author with previously articulated poses and masks.

KEYWORDS: Author. Performance. Contemporary Literature.

\section{Introdução}

A noção de autor passou por momentos distintos ao longo da história, sendo construída culturalmente. Enquanto na contemporaneidade vivemos um momento em que o autor é parte fundamental da sua obra, tornando-se inclusive um ícone midiático, na

\footnotetext{
1 Mestra em Letras pela Universidade Estadual do Maranhão (UEMA). Professora substituta do Departamento de Letras, do Centro de Ensino Superior de Presidente Dutra - CESPD/UEMA. Contato: ab.duailibe@gmail.com
} 

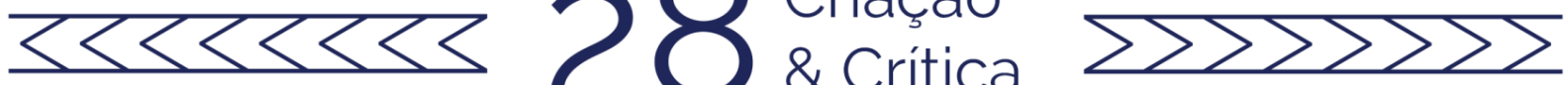

Antiguidade, até meados da Idade Média, não havia uma preocupação de estabelecer a autoria de uma obra. As histórias produzidas não eram assinadas por seus autores, passando por um processo contínuo de criação, permitindo que conteúdos fossem incluídos, retirados ou modificados em qualquer parte do ato narrativo, no momento de sua reprodução. Naquele período, a autenticidade e o valor das histórias relacionavam-se a sua tradição, sem a preocupação de que fossem assinadas por um autor.

Esse cenário modifica-se somente a partir do Renascimento, quando o homem passa a se reconhecer como indivíduo. Nesse ínterim, surgem também os primeiros indícios da propriedade privada, na qual também se inserem os discursos que, a partir de então, poderiam ser passíveis de punições. Segundo Foucault (2002), em sua origem, o discurso não era considerado como um bem ou um produto. Essencialmente, era um ato - dicotomicamente classificado em sagrado ou profano, tornando-se, posteriormente, um bem preso em um circuito de propriedades. Assim, o autor surge como uma categoria de invenção histórica, oriunda do momento no qual irrompem as noções de burguesia, capitalismo, propriedade privada e lucro. E, por consequência, a individualidade.

A noção de autor constitui o momento forte de individualização na história das ideias, dos conhecimentos, das literaturas, na história da filosofia também, e na das ciências. Mesmo hoje, quando se faz a história de um conceito, de um gênero literário ou de um tipo de filosofia, creio que tais unidades continuam a ser consideradas como recortes relativamente fracos, secundários e sobrepostos em relação à unidade primeira, sólida e fundamental, que é a do autor e da obra (FOUCAULT, 2002, p. 33).

Neste contexto de apropriação de valores, conhecimentos e objetos, a noção de propriedade privada, fruto do capitalismo, transforma o autor em um sujeito proprietário que possui o livro como seu artefato; em um nome produzido num momento histórico em que não há mais espaço para o anonimato, uma vez que passa a possuir direitos autorais sobre a sua produção.

Em O que é um autor? Revisão de uma genealogia, Roger Chartier (2014) vai de encontro à cronologia apresentada por Foucault. $\mathrm{O}$ historiador acredita que o nascimento do autor se trata do resultado de um processo oriundo do Antigo Regime. Assim, a emergência da propriedade literária deve ser remontada ao começo do século XVIII, sendo atribuída a um direito já existente e consolidado desde o século XVI: o privilégio dos livreiros europeus de reproduzir e comercializar um texto que fora adquirido junto a um determinado escritor.

Em seu livro, Chartier (2014) relembra o Estatuto da Rainha Ana. Em 1709, após votação do Parlamento inglês, houve uma alteração das práticas de publicações de textos na Inglaterra, estremecendo assim o monopólio da propriedade literária dos livreiros, os quais, diante dessa ameaça, conceberam ao copyright - o direito de propriedade sobre a sua obra.

Essa prática fora ancorada em dois argumentos: o primeiro, de ordem filosófica "segundo o qual todo homem deve gozar do direito natural de ser proprietário dos frutos 

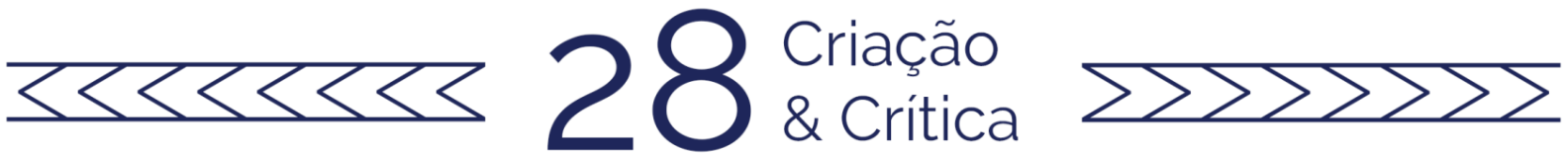

de seu trabalho"; e o segundo, de ordem estética, "segundo qual se deve defender a propriedade do autor sobre os seus textos, em função de sua originalidade e da singularidade de sua produção, seu gênio criador" (CHARTIER, 2014, p. 14).

A partir desse fato, os livreiros reclamaram a atribuição da propriedade literária àquele que escreve - o escritor, que deveria ter o direto a se dispor do fruto de seu trabalho, podendo vender, ou transferir aos demais, o direito sobre o seu texto e suas futuras reproduções.

Desta forma, Chartier (2014) constata o paradoxo fundamental da emergência do sistema jurídico em que se instaura a figura do autor moderno:

De um lado, sustentavam-se valores burgueses que advogam o direito comum, indistinto e natural a todos os indivíduos e suas produções; de outro, essa sustentação em valores burgueses teve por objetivo a defesa e perpetuação de velhos privilégios, aristocráticos e tradicionais, próprios do Antigo Regime (CHARTIER, 2014, p. 14).

Independente da sua "origem", o autor é um dos pontos mais controvertidos dos estudos literários. Segundo Compagnon (2014), podemos dividir a relação entre o texto e seu autor em duas correntes distintas: a antiga - que identificava o sentido da obra à intenção do autor; e a moderna - que defende o "apagamento do autor" e a interpretação literária como descrição apenas das significações da obra defendida pelo Formalismo Russo, o New Critics americano e o Estruturalismo francês.

Com a potencialização da cultura midiática, no entanto, a figura do autor ultrapassa as duas correntes apontadas por Compagnon, aparecendo agora como um personagem do espaço público, que possui imagens vinculadas a diferentes esferas comunicativas. Assim, o presente artigo volta-se para a construção de um percurso teórico ao apresentar alguns estudos estruturalistas e formalistas que defendem 0 apagamento dessa categoria - como os postulados de Foucault (2002) e Barthes (2004) e, na sequência, a guinada subjetiva, expressão de Beatriz Sarlo, que possibilitou o retorno do autor na cena contemporânea, usando como alicerce teórico os estudos de Lejeune (2014), Klinger (2012), Schollhammer (2011), Aguilar e Cámara (2017), Hoisel (2019), dentre outros.

\section{O apagar daquele que escreve: a morte do autor}

Em meados dos anos 20, a figura autoral passa a ser descentralizada. Com intuito de evitar os estudos geneticistas da literatura e sacralização do autor - como aquele que é a origem e a explicação de toda a obra - o Formalismo Russo propõe a autonomia do texto literário, que seria, então, um objeto autônomo de investigação. Os formalistas defendiam a necessidade de desprezar os fatores extrínsecos ao texto, delimitando-se ao estudo intrínseco da obra literária.

Associado ao Formalismo Russo, o Estruturalismo também despreza as informações extratextuais do texto literário. Considera que o autor é o passado do livro e 

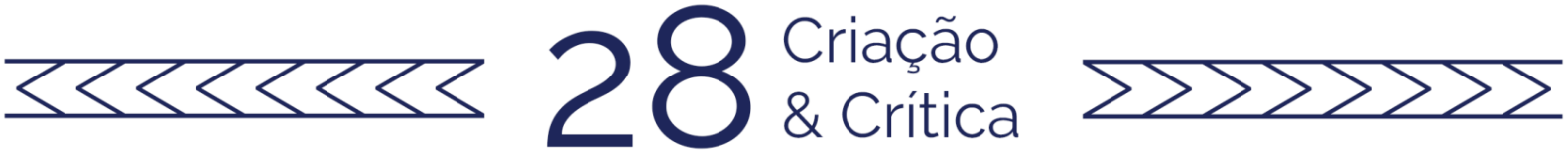

uma vez que esse é escrito no presente, no momento em que nasce o escritor e o seu texto, a existência de quem escreve não deve ocupar um espaço de maior importância. Assim, tanto os estruturalistas quanto os formalistas defendiam a exclusão da figura autoral, voltando-se ao texto, exclusivamente. O autor, desta forma, permaneceria distante dos estudos literários, aspecto que, segundo Compagnon (2014), asseguraria a independência desses estudos em relação à história e à psicologia, por exemplo, uma vez que a figura autoral representava o humanismo e o individualismo que a teoria literária tentava eliminar.

O Estruturalismo encontra o auge da sua expressão em dois textos que se tornaram pilares desse movimento: A morte do autor (2004), de Roland Barthes e $O$ que é um autor? (2002), de Michel Foucault. Para os estruturalistas, o autor, ao construir a sua obra, aceita o seu próprio desaparecer, pois somente a obra, por meio da linguagem nela empregada, é capaz de falar. Sob a ótica estruturalista, o autor não faz parte da estrutura linguística que compõe a obra, ficando à margem dos estudos literários, o que justificaria então o desaparecimento do autor na literatura.

Barthes, em $A$ morte do autor (2004), apresenta-nos a dificuldade em delimitar de quem é a voz que escreve, já que a escrita é a destruição de toda origem e de toda voz, onde se perde toda a identidade, iniciando-se pelo corpo daquele que a escreve. Sendo assim, seria a linguagem responsável pela fala, não o autor. Segundo Barthes, "o autor nunca é mais do que aquele que escreve, [...] a linguagem conhece um sujeito, não uma pessoa, e esse sujeito fora da enunciação que o define, basta 'sustentar' a linguagem, isto é, para exauri-la" (2004, p. 60), ou seja, no momento em que o sujeito assume a linguagem, ele apenas se apodera de algo que já fora reproduzido anteriormente.

Com o afastamento do autor, não teríamos como atribuir uma identidade textual à obra. Essa perspectiva torna-se responsável por transformar, radicalmente, os textos modernos: enquanto antigamente o autor era responsável por explicar e dar sentido a sua obra, agora tal relação passa a se apresentar a partir de outros textos, uma vez que "o escritor moderno nasce ao mesmo tempo em que o seu texto [...] não existe outro tempo além do da enunciação, e todo texto escrito é eternamente 'aqui' e 'agora'” (BARTHES, 2004, p. 61, grifos do autor), excluindo, assim, uma relação de antecedência.

Afastando-se a ideia de que texto é produzido com um único sentido dado pelo "Autor-Deus" e aproximando-se do pensamento de que esse é "um espaço exato em que todos se inscrevem, sem nenhuma perda" (BARTHES, 2004, p. 63), aumenta-se o poder do leitor, que é capaz de reunir, em um mesmo campo, os diversos traços constituintes do escrito, criando possíveis significações do texto literário. Assim, o leitor torna-se a instância articuladora do texto, "cuja existência restringe-se ao ato de leitura e ao ato de produção textual, embora não tenha história e nem seja uma pessoa, ele tem várias histórias no sentido de ser o responsável pelas diferentes maneiras de ler um texto" (CAVALHEIRO, 2008, p. 72).

Anos depois, em O prazer do texto (1989), Barthes retoma suas postulações sobre a questão do texto e do escritor. Nesse ensaio, Barthes não descarta a 

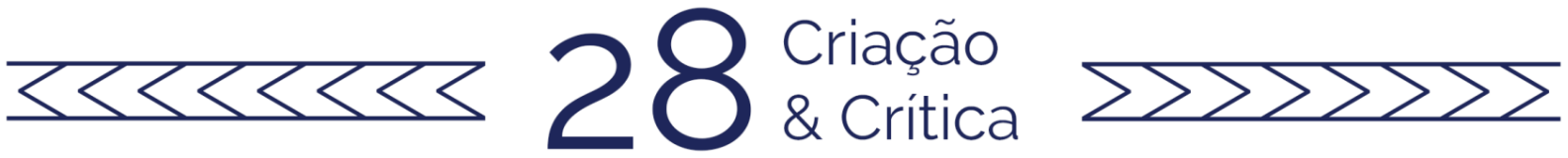

possibilidade de um retorno do autor, mas assegura que este será de uma forma distinta: não mais como um ser unitário, mas sim em termos plurais. Logo, o leitor precisará reconhecer a voz com a qual ele irá se apegar durante a leitura da obra.

Como instituição, o autor está morto: sua pessoa civil, passional, biográfica, desapareceu; desapossada, já não exerce sobre sua obra a formidável paternidade que a história literária, o ensino, a opinião tinham o encargo de estabelecer e de renovar a narrativa: mas no texto, de uma certa maneira, eu desejo o autor: tenho necessidade de sua figura (que não é nem sua representação nem sua projeção), tal como ele tem necessidade da minha (salvo no "tagarelar") (BARTHES, 1989, p. 37).

Não haveria, desse modo, a necessidade de falar sobre o autor no momento da leitura/estudo de uma obra, visto que esse não passaria de um ser de papel. Barthes, entretanto, admitira a presença do autor em entrevistas de periódicos, manuais de obras literárias e em outras expressões literárias. Seu receio centrava-se não em, de fato, alijar a figura autoral, mas sim impedir que Ihe fosse dado o fim último da obra literária.

No ensaio O autor e a personagem (2003), Bakhtin destaca que um dos principais equívocos dos trabalhos históricos-literários consistia em extrair um possível material biográfico das obras, relevando "coincidências" entre as vidas dos personagens e do autor. Apesar das tentativas em dissociar as noções entre autor biográfico e a intenção do autor, a figura autoral nunca deixou de ser associada à noção de obra. Assim, o teórico nos alerta sobre uma constante confusão entre o autor-criador, elemento constituinte da obra, e autor-pessoa, componente da vida pessoal.

O autor-criador faz parte do objeto estético como aquele que lhe dá forma, sendo "a consciência que abrange a consciência e o mundo da personagem". Assim, Bakhtin ratifica que

o autor reflete a posição volitivo-emocional da personagem e não sua própria posição em face da personagem; [...] o autor cria, mas vê em sua criação apenas no objeto que ele enforma, isto é, vê dessa criação apenas o produto em formação e não o processo interno psicologicamente determinado (BAKHTIN, 2003, p. 5).

É justamente esse excedente de visão possibilita ao autor-criador o princípio de acabamento ao objeto estético, baseando-se em uma relação de exotopia - uma consciência fora de outra consciência, que se refere a uma consciência que vê a outra como um todo acabado, aspecto que não consegue fazer consigo mesma. Essa atividade estética se dá quando o autor-criador é capaz de retornar a si mesmo, para então, dar acabamento ao outro, a partir de seu excedente de visão.

O apagamento dessa categoria, no entanto, não é simples. Para Foucault (2002), a morte do autor é concepção de que esse é apenas um vocábulo criado para produzir efeitos demarcados, para exercer uma determinada função. Uma invenção histórica, não um sujeito absoluto, que é "característica do modo de existência, de circulação e de alguns discursos no interior de uma sociedade". 

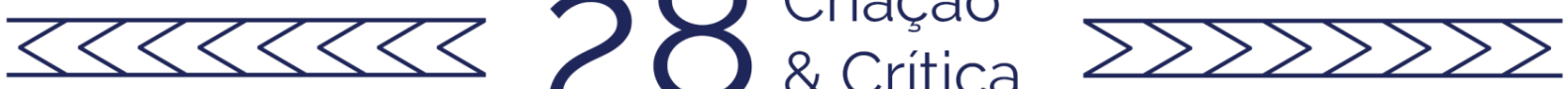

Em O que é um autor?, Foucault reflete acerca da "relação do texto com o autor, a maneira como o texto aponta para essa figura que lhe é exterior e anterior, pelo menos em aparência" (2002, p. 34). Em sua análise, apresenta uma regra imanente da escrita que a domina enquanto prática, exemplificando-a a partir de dois temas: o tema da expressão e o tema da morte. No que tange a expressão, a escrita faria referência somente a si própria, não importando quem escreve, já que a obra se bastaria por si mesma; um espaço no qual o sujeito da escrita está sempre a desaparecer. No que diz respeito à morte, apresenta uma relação entre a escrita e as epopeias gregas que se destinavam a perpetuar a imortalidade do herói; como também entre a escrita e as narrativas árabes, que tinham como pretexto adiar a morte, assim como em Xerazade.

Na cultura moderna, no entanto, tem-se uma inversão da relação entre a escrita e a imortalidade. Para Foucault (2002, p. 34), a escrita está ligada ao sacrifício da vida do escritor, ao apagamento necessário dos caracteres individuais do sujeito que escreve, uma vez que "a marca do escritor já não é mais que a singularidade de sua ausência".

Em paralelo, também propõe uma retomada do caráter absoluto e fundador do sujeito autor - categoria que sustenta os conceitos de obra e de unidade -, reconhecendo que a lacuna deixada por esse afastamento precisaria ser preenchida, sugerindo assim, uma função autor que viria a caracterizar o modo de circulação e funcionamento dos discursos nas diversas sociedades em que ocorrem.

Desse modo, enumera quatro particularidades da função autor: 1) a função de propriedade, que remete à possibilidade de punição daquele que o escreve; 2) a genealogia do texto, uma vez que é necessário saber quem o escreveu para atribuir determinado valor ao texto literário; 3) a construção de um outro ser chamado autor, a partir de projeto em que se originaria a escrita e que se finda ao término dela; 4) a criação de um alter ego, uma vez que não poderíamos acreditar que as referências utilizadas na narrativas são, de fato, daquele que escreve.

A escritura, assim, seria um espaço no qual o sujeito que escreve desaparece, cuja marca se dá apenas na singularidade da sua ausência. A partir dessas postulações, Agamben, em $O$ autor como gesto (2007), traz reflexões sobre a ausência/presença do autor no texto literário. Assim como Foucault, parte da célebre frase de Beckett: "o que importa quem fala, alguém disse, o que importa quem fala". Agamben acredita que se alguém anônimo e sem rosto proferiu esse enunciado, esse alguém é de extrema importância, uma vez que sem a sua presença, a tese não poderia ser formulada. Assim, o mesmo gesto que nega a sua relevância, afirma a necessidade daquele que fala.

Desse modo, o autor não precede às obras literárias, mas se faz presente nelas por meio, apenas, dos processos de subjetivação que a constituem e dos dispositivos que a inscrevem. Assim,

a subjetividade se mostra e resiste com mais força no ponto em que os dispositivos capturam e põem em jogo. Uma subjetividade produz-se onde o ser vivo, ao encontrar a linguagem e pondo-se nela em jogo sem 

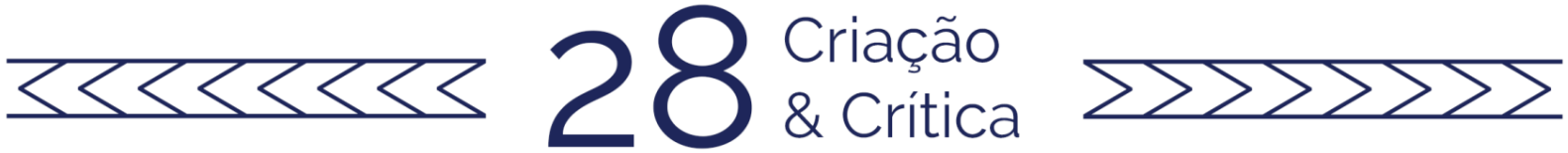

reservas, exibe em um gesto a própria irredutibilidade a ela (AGAMBEN, 2007, p. 58).

Agamben (2007) chama de gesto aquilo que continua oculto em cada ato de expressão. Nessa perspectiva, o autor está presente no texto apenas como um gesto e possibilita a sua expressão ao mesmo tempo em que instala um vazio central. Por conseguinte, a intepretação se dá a partir do gesto em o autor e o leitor se colocam em jogo, embora o primeiro estabeleça um limite para o qual nenhuma interpretação é capaz de ir.

A figura do autor descrita por Agamben (2007) apresenta-se como um protagonista de sua própria ficção, seja ela escrita, cinematográfica ou a partir de redes sociais. Apesar do ideal foucaultiano de 'ignorar aquele quem fala', a figura autoral nunca deixou de ser associada à noção de obra. Partindo dessa conjectura, seria possível, hoje, no seio de uma sociedade midiática, desprezar todos os signos extratextuais e fazer uma leitura essencialmente textual da obra literária? Seria possível destruir, então, a identidade do corpo daquele que escreve?

\section{O retorno do autor na cena contemporânea}

Para os estruturalistas, o autor, ao construir a sua obra, aceita o seu próprio desaparecer, uma vez que somente a obra, por meio da linguagem nela empregada, é capaz de falar. Sob essa ótica estruturalista, o autor não faz parte da estrutura linguística que compõe a obra, ficando à margem dos estudos literários, o que justificaria então o seu desaparecimento na literatura.

O apagamento dessa categoria, mesmo para os estruturalistas, no entanto, não é simples. Foucault, ao reconhecer a dificuldade desse desaparecimento, propõe as diversas nuances da função-autor enquanto substituta. Barthes, mesmo defendendo o apagamento de sua figura do autor, reconhece que "o autor reina ainda nos manuais de história literária, nas biografias de escritores, nas entrevistas das revistas, e na própria consciência dos literatos, preocupados em juntar, graças ao seu diário íntimo, a sua pessoa e a sua obra" (BARTHES, 2004, p. 66). Nota-se, assim, que a maior preocupação dos estruturalistas não era excluir a figura do autor da cena literária, mas impedir que ele fosse interpretado como a palavra final do texto. Ao ignorar uma leitura geneticista da obra, dava-se a necessária autonomia para a análise textual.

A problematização acerca da noção de autor e sua influência na obra literária ganha espaço na literatura contemporânea. No cenário brasileiro, autores como Cristovão Tezza, Silviano Santiago, Bernardo Carvalho e Ricardo Lísias trazem à voga narrativas que embaralham as categorias de ficção e de realidade, nas quais há um traço marcante de presentificação, nas palavras de Beatriz Resende, visível em seus processos criativos.

De acordo com Schollhammer (2011, p. 13), nos escritores da geração mais recente, "há certamente uma preocupação pela criação da sua própria presença, tanto no sentido temporal mais superficial de tornar-se a ficção do momento, quanto no sentido mais 

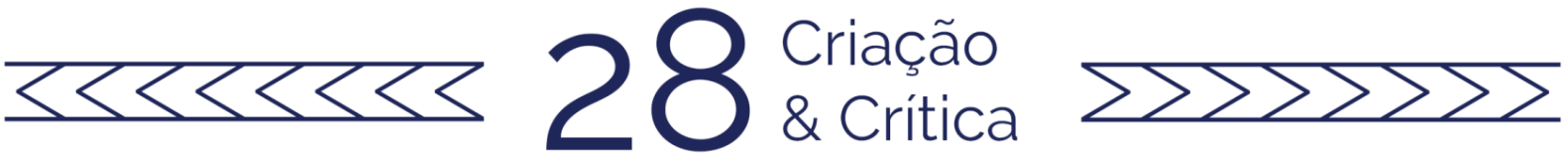

enfático de impor sua presença performativa". Nesse sentido, anular o corpo daquele que escreve, como nos propôs Barthes, torna-se uma grande problemática ao nos voltarmos para a literatura contemporânea, em que há uma transgressão da figura autoral.

Phillipe Lejeune, em A imagem do autor na mídia (2014), faz uma retrospectiva histórica sobre o espaço ocupado pela categoria autor. Inicialmente, os textos literários eram os responsáveis por incitar no leitor o desejo de conhecer, de buscar informações sobre aquele que escreve. A pessoa do autor não era conhecida do grande público e seu contato com os leitores não ultrapassava as páginas dos livros, o que lhe dava um certo ar de sacralidade. Para sanar o vazio de informações, visto que os periódicos forneciam poucas ilustrações e fotos do autor, os leitores recorriam a biografias canônicas, no intuito de aproximarem-se daqueles pelos quais tinham admiração.

Como satisfazer o desejo carismático, inspirado pelo autor, de conhecer e entrar em contato? Antigamente, para preencher essa falta engrenada pelo escrito, ficava-se reduzido a recorrer a outros escritos, de gênero um pouco diferentes [...]. Quanto a ver ou ouvir o próprio autor, nem se pensava nisso, a menos que o acaso permitisse ou que se escrevesse ao autor solicitando um encontro, para tentar uma relação pessoal que provocasse um curto-circuito com no texto impresso (LEJEUNE, 2014, p. 226).

A partir do século $X X$, com a potencialização da cultura midiática, outras formas não canônicas passam a servir de aproximação entre o leitor e o escritor. A constante participação midiática dos autores traz um efeito contrário aquele primeiramente estabelecido; se anteriormente era o livro que incitava o desejo de aproximar-se do autor, na atualidade, muitas vezes, há uma subversão dessa lógica fetichista: a performance do autor, enquanto sujeito midiático-literário, é capaz de despertar o interesse do leitor em suas produções.

Na televisão, enfim, voz e imagem se reuniram. Nada mais a ser imaginado: o autor do livro que lemos ou, com mais frequência, do livro que não lemos e que não leremos está ali, em carne e osso e ao vivo. Se ainda restar algo a ser imaginado, será, paradoxalmente, o que ele terá escrito (LEJEUNE, 2014, p. 227-228).

Nesse ínterim, com a sua constante presença na mídia, torna-se difícil ignorar a presença do autor, crescendo assim, o interesse pela figura autoral. Segundo Viegas (2007), assistimos hoje a um retorno do autor, mas não trazendo à voga os receios estruturalistas de torná-lo o centro do texto e explicação única e última de sua obra, mas sim como uma figura midiática, como um personagem do espaço público. Anos antes, a imagem dos escritores não alcançava o grande público, no entanto, hoje, "ao lermos um texto, não temos apenas o nome autor como referência, mas sua voz, seu corpo, sua imagem veiculada nos jornais, na televisão e na internet" (VIEGAS, 2007, p. 18), aspecto que nos comprova a existência de uma figura autoral e nos distancia da concepção barthesiana de autor enquanto um ser de papel. 

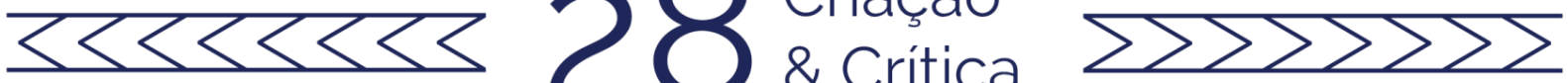

Ademais, o escritor contemporâneo tem um papel ativo no cenário editorial, uma vez que o autor "deve induzir o desejo de ler seus textos, ao passo que antes, era o texto que despertava o desejo de se aproximar dele" (LEJEUNE, 2014, p. 227). Além de assumir a autoria dos textos que escreve e promovê-lo em diversas esferas sociais feiras literárias, programas de televisão, canais na internet e redes sociais - alguns escritores adentram, ainda, em sua própria trama, enquanto personagens e matéria de sua ficção.

Para Viegas (2007, p. 15), a discussão em torno da figura autoral na contemporaneidade passa por um "exame da teorização contemporânea do sujeito". Um dos motores da formação do sujeito moderno foram as diversas modificações da escrita de si, que também coloca em voga questões sobre relatos autobiográficos e autoria, culminando em uma maior atenção em torno da pessoa do escritor.

A atenção em torno da pessoa do escritor cresceu, e a figura espetacular do autor tanto quanto o objeto livro ganharam maior espaço na mídia - o que não coincide com o ganho de leitores efetivos; tornou-se chique ser autor, e nada incomum ganhar espaço na mídia antes mesmo de publicar o seu primeiro livro. (SCHOLLHAMMER, 2011, p. 19).

No horizonte midiático da cultura contemporânea, observa-se não somente a notoriedade adquirida pelo autor, como também o surgimento de novas expressões que derivam dos canônicos gêneros autobiográficos. O seu avanço trouxe uma maior visibilidade do privado que reflete em um maior interesse pelo alheio, pela intimidade; aspecto que trouxe um recrudescimento de reality shows, blogs e demais redes sociais, além de influenciar a proliferação de publicações como autobiografias, entrevistas, cartas e memórias editadas.

O homem contemporâneo fascina-se com o vislumbre da intimidade alheia, aspecto que faz com que a visibilidade do íntimo se apresente como um dos principais registros da cena contemporânea, criando um espaço de "indecidibilidade entre o público e o privado" (VIEGAS, 2007 p.16). Com uma característica fortemente imagética, marcada pelo vouyeurismo, em que se rompe as barreiras do público e do privado, estamos inseridos em

uma cultura midiática que manifesta uma ênfase tal do autobiográfico, que leva a pensar que a televisão se tornou um substituto secular do confessionário eclesiástico e uma versão exibicionista do confessionário psicanalítico (KLINGER, 2012, p. 15).

No espaço biográfico contemporâneo, segundo Arfuch (2002), há um crescimento da narrativa vivencial, contemplando diversos registros de lógicas midiáticas, literárias e acadêmicas, no qual a significação não se limita aos múltiplos relatos autobiográficos, mas a uma constante apresentação biográfica desta multiplicidade de relatos, fator que assegura uma maior relevância ao biográficovivencial nos gêneros discursivos contemporâneos. 

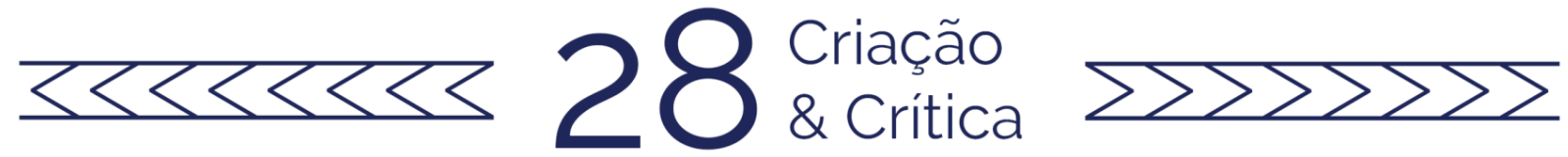

Neste universo indecidível entre o que seria real e ficcional, há um suplemento de sentido nas vidas reais que a literatura, a televisão, o cinema, a internet e os demais mecanismos midiáticos se empenham em divulgar. Há modelos sociais em que o espaço biográfico tende a desdobrar-se, delineado a partir de um forte traço midiático que nos leva a uma identificação, seja pela presença ou pela ausência de determinadas especificidades. Essa identificação é validada a partir de um certo olhar do outro. Proliferam-se, assim, fórmulas de autenticidade, de obsessão do vivido e o mito do personagem real.

Em O show do eu: a intimidade como espetáculo (2016), Sibilia explana sobre o crescente interesse da sociedade do espetáculo pela intimidade alheia, resultando em fenômeno da espetacularização da vida privada não só de famosos, mas também de desconhecidos, tanto por meio das novas mídias quanto a partir de biografias, cartas editadas, autoficções e blogs na Internet - nas quais a exaltação da própria vida e o interesse pela de outrem se transforma em um objetivo de especulação do capital.

A autora analisa esse momento de superposição do autor em relação a sua obra, apresentando três possíveis justificativas para esse evento. A primeira relaciona-se a separação das concepções entre artista e artesão, perspectiva que torna o processo em si mais relevante do que a obra acabada. O segundo argumento está pautado na valorização do "novo" no viés artístico, uma vez que a mídia exalta sempre outra novidade instantânea. Por fim, e mais importante, Sibilia apresenta como justificativa a delimitação daquele que é artista e daquilo que pode ser considerado arte por parte da mídia. Esses fatores contribuem para transformar o autor em uma celebridade (que chama atenção para si e para sua privacidade) e a sua obra, em um verniz artístico.

A busca da sociedade pelo íntimo, pelo privado, pelos "efeitos do real"2, torna ainda mais tênue a linha que separa ficção da realidade, estreitada a partir da "ficcionalização do real na mídia, bem como a gradativa naturalização do realismo na ficção" (SIBILIA, 2016, p.196). A espetacularização da intimidade, aqui, não se limita a um conjunto de imagens, mas expande-se para a construção de uma relação social. As redes sociais, por exemplo, aparecem como principal cenário de espetacularização. Cria-se uma personalidade que se legitima a partir de seus posts compartilhados na tela, na qual pessoas comuns tornam-se autores de sua própria fiçcão.

Espetacularizar o eu consiste precisamente nisso: transformar as nossas personalidades e vidas (já nem tão) privadas em realidades ficcionalizadas com recursos midiáticos. É isso que se procura fazer ao performar a própria extimidade nas telas cada vez mais onipresentes e interconectadas (SIBILIA, 2016, p. 249, grifos da autora).

\footnotetext{
${ }^{2}$ Segundo Barthes (2004), tal efeito ocorre quando se tenta legitimar, por diversas fontes, uma informação apresentada dentro da narrativa. Para isso, faz-se uso de diversos artifícios para conferir a verossimilhança interna da fiç̧ão. Ressalta-se aqui o uso daquilo que o autor apresentou como biografemas, que são capazes de imprimir novas significações ao texto, sendo utilizadas como pontes entre a realidade e a ficção.
} 

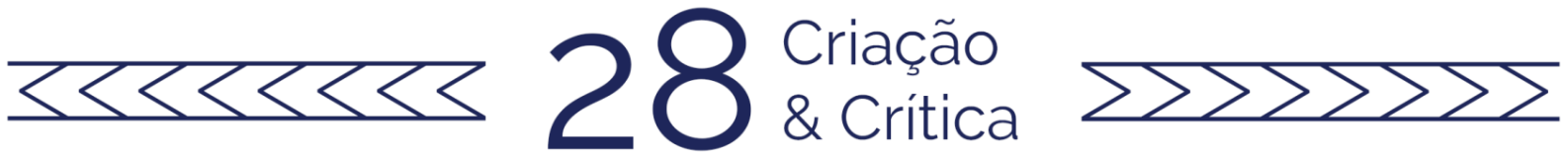

Assim, quanto mais a vida cotidiana é ficcionalizada com recursos midiáticos, mais procura-se uma experiência autêntica e não encenada. Ao longo da era moderna, a arte imitava a vida (será que a vida também imitava a arte?), no entanto, a crescente ficcionalização do real na mídia contribui, de forma significativa, para mudanças no contorno da realidade, proliferando narrativas que retratam a vida como ela é.

As narrativas de ficção parecem ter perdido boa parte de sua hegemonia inspiradora para a autoconstrução de leitores e espectadores, com uma crescente primazia de seu suposto contrário: o real - ou, mais precisamente, a não-ficção (SIBILIA, 2016, p. 249).

A partir dessa perspectiva, o autor que retorna à cena contemporânea não é aquela figura sacrossanta do texto, que fora excluído por Barthes e Foucault, mas um autor que participa de sua própria criação como escritor, personagem e promotor de seu texto, sem, no entanto, deter a verdade sobre ele; "um autor que retorna não como garantia última da verdade empírica e sim apenas como provocação, como forma de um jogo que brinca com a noção do sujeito real” (KLINGER, 2012, p. 46), para o qual já não cabe mais o pacto autobiográfico postulado por Lejeune - um contrato de leitura entre 0 autor e o leitor, no qual consistem princípios de verdade e identidade.

$\mathrm{Na}$ crítica contemporânea, fala-se muito de um "retorno do autor", e há claramente, na literatura e na própria crítica contemporânea, uma acentuada tendência em revalorizar a experiência pessoal e sensível como filtro de compreensão do real. Nesse movimento, são revalorizadas as estratégias autobiográficas [...] Nessa renovada aposta na tática da autobiografia, dilui-se a dicotomia tradicional entre ficção e não ficção, e a ficcionalização do material vivido torna-se um recurso de extração de uma certa verdade que o documentarismo não consegue lograr e que não reside numa nova objetividade do fato contingente, mas na maneira como o real é rendido pela escrita (SCHOLLHAMMER, 2011, p. 106-107).

A essa tendência literária contemporânea capaz de diluir as fronteiras entre a realidade e a ficção, vários teóricos denominam de autoficção, termo inicialmente criado pelo escritor francês Serge Doubrovsky, sendo compreendido como "a ficção de fatos e acontecimentos estritamente reais" (DOUBROVSKY, 2014, p.120). Aqui, optamos por compreendê-la como um texto fronteiriço entre o ficcional e o referencial, que embaralha as categorias de autobiografia e ficção; marcado pela incerteza e por uma escrita subjetiva, que mesmo trazendo em seu bojo aspectos referenciais, ficcionaliza-os a partir do momento em que os escreve.

Acerca desta tipologia, Colonna (2004) constata que o modelo definido por Doubrovksy é apenas uma de várias manifestações da autoficção, que se refere a uma fabulação de si. Para tanto, apresenta quatro tipologias que representam as diversas formas de expressão da escrita autoficcional: a fantástica - na qual o escritor está no centro do texto, tal como em uma autobiografia; a biográfica - em que o escritor é o herói da sua narrativa, fabulando-se a partir de dados reais; a especular, baseada em um 

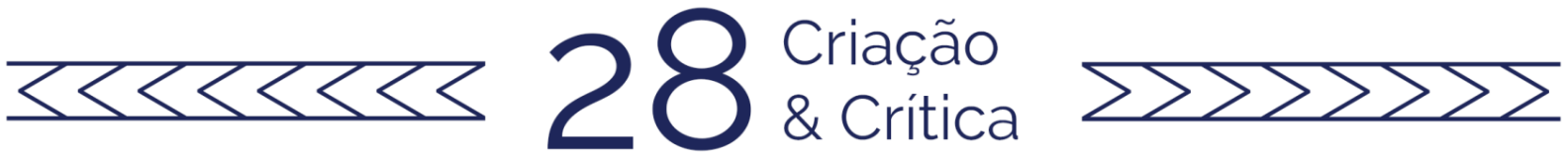

reflexo do autor ou do livro dentro do próprio livro, assimilando-se a metáfora do espelho; e a intrusiva ou autoral, na qual a transformação do autor acontece a partir de um narrador-autor, que supõe um romance na terceira pessoa. ${ }^{3}$

Neste mesmo paradigma, em Autoficção é o nome de que? (2006), Gasparini apresenta uma análise acerca da evolução do termo durante os últimos 20 anos, o qual distancia-se de seu conceito inicial, desdobrando-se em novas formas de escrita. $\mathrm{O}$ autor parte da hipótese de que "a autoficção é o nome de um gênero ou de uma categoria genética [...] que se aplica a textos literários contemporâneos" (GASPARINI, 2009, p.181), responsável por estimular as reflexões acerca dos gêneros literários e sobre os limites da literatura, questões propostas desde a poética de Aristóteles.

Assim, considerando a escrita autoficcional como uma representante da contemporaneidade, marcada por um cenário de ambiguidades, fragmentação e incertezas, a autoficção estaria na encruzilhada entre o exibicionismo típico da cultura midiática e o retorno do autor, aspecto esse não somente literário, mas também epistemológico, relacionado à crítica filosófica do sujeito, uma vez que "problematiza a relação entre as noções de real (referencial) e de ficcional, assim como a tensão entre a presença e a falta" (KLINGER, 2012, p.40). O retorno do autor coincidiria, então, com o retorno do real que se apresenta a partir de um efeito performático. Dessa forma, "o efeito de tempo real produzido [...] se revela como a função de um desejo - uma fome de real' (KLINGER, 2012, p.45).

A autoficção refere-se a um discurso que não se relaciona com o extratextual, como no caso da autobiografia, mas que, no entanto, também não está completamente desvinculado dele, participando "da criação do mito do escritor, uma figura que se situa no interstício entre a 'mentira' e a 'confissão"' (KLINGER, 2012, p.56), estabelecendo-se entre a autobiografia e a ficção; e apontando para possíveis experiências da escrita de si, nas quais o ficcional tem possibilidade de entrar a qualquer momento, reinserindo a figura do autor na cena contemporânea.

\section{Uma figura performática: autor ou ator?}

O autor reinsere-se na cena contemporânea ao reconfigurar o real não somente em seu livro, mas também em signos extratextuais, como em feiras, entrevistas e canais da internet, ao embaralhar as noções de ficção e realidade para além do texto, assumindo um caráter performático que faz parte da sua produção. As conexões feitas entre a vida daquele que escreve e a sua obra servem para construir um mito - que não se aproxima da verdade, no entanto também não se afasta dela.

Se anteriormente Barthes defendia que o escritor moderno surgia no momento da escrita do seu texto, podemos, em analogia, inferir que, agora, é a representação da

\footnotetext{
3 Acerca da autoficção, recomendamos a leitura de Colonna (2004); Gasparini (2006); Lecarme (1993); Vilain (2009) e demais textos que compõe a coletânea Ensaios sobre a autoficção (2014), organizada por Jovita Maria Gerhein Noronha.
} 

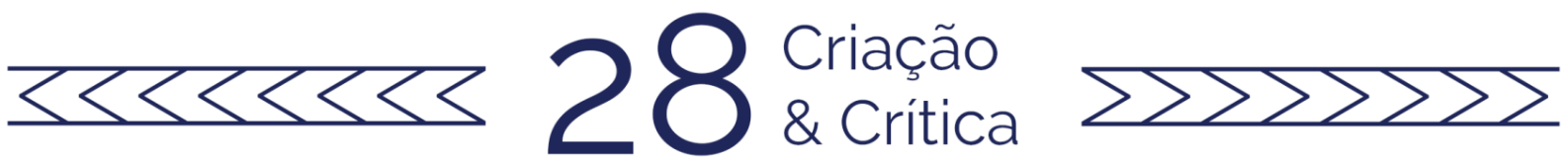

realidade que se ergue no momento da construção do discurso. A verdade ali exposta não é prévia, não é real. $O$ autor constrói o texto, e também a si mesmo, a partir de uma performance que utiliza

uma exibição de fragmentos do mundo, que abordam um processo de movimento ao desestabilizar as sólidas posições do autor, personagem e leitor. Essa espécie performativa consegue relativizar a realidade referida pela narrativa na construção de um perspectivismo complexo, que concretiza a situação de exibição e observação ao questionar a realidade representada tal como aparenta espontaneamente (SCHOLLHAMMER, 2011, p. 110).

A construção dessa figura pauta-se por um fio de tensão entre a vida pública, a instituição, o escritor e o mercado. De acordo com Aguilar e Cámara (2017, p. 22), "essa construção passa não só por suas obras [...] há frequentemente operações deliberadas [...] que não ocorrem no vazio, e sim interagem com condições de visibilidade e discursividade determinadas". Assim, a performance autoral é marcada, segundo os autores, por dois dispositivos que funcionam de forma complementar: máscara e pose. A máscara necessita do discurso, sendo constituída pela obra poética ou ficcional, expandindo-se para todo texto ou discurso público do autor. Enquanto a pose volta-se para o corpo, para os aspectos visuais: desde suas roupas e gestos até a sua presença em determinadas localidades.

A vida literária encarada não a partir da noção de campo, mas da noção de performance deixa ver uma dinâmica em que pose e máscara são constantemente negociadas. Vestimenta, corte de cabelo, romance, foto de orelha, poesia, blog ou post de facebook contribuem para que se leita um texto de uma ou de outra maneira (AGUILAR; CÁMARA, 2017, p. 24-25).

A performance do autor, neste ínterim, rompe com o ideal performático centrado no corpo do artista. Está imbricada à atuação dos escritores em eventos literários e redes sociais não somente como meio de divulgação de seus trabalhos, mas também como suporte ficcional para suas obras. Esse deslocamento indica um certo trânsito entre a literatura e vida "real" (seria então a realidade nada mais que uma ficção?) de um autor que circula por diversos espaços e torna possível seu diálogo com o público.

O mercado exige cada vez mais a presença do autor, tanto no eixo presencial com participações em feiras literárias, congressos e simpósios, quanto no virtual, em que utilizam seus perfis em diversas redes sociais para dividir posicionamentos e incitar discussões e autopromoções. Nessa medida, "poses e máscaras se redefinem e se tencionam, entre as demandas de uma cultura atravessada por estratégias de marketing de tipo empresarial e o gesto autoral busca para si certa singularidade" (AGUILAR; CÁMARA, 2017, p. 153). 

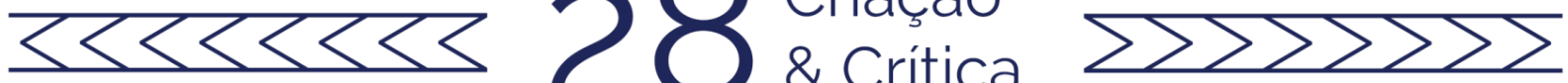

Nessa perspectiva, o contexto autoral não é um requisito confiável, uma vez que a figura desse autor que retorna na cena contemporânea, nada mais é do que um ato performático cuidadosamente construído.

A ilusão aumenta proporcionalmente com a impressão de realidade criada pela mídia [...]. Acredita-se ver o homem ao natural e se esquece que toda e qualquer participação em programas de rádio de televisão implica a construção de um papel ditado pela posição atribuída àquele homem. $\mathrm{O}$ papel do autor é pré-construído pela expectativa do público visado [...]. O autor já viu ou ouviu ele próprio [...] e se preparou para fazer boa figura. E cauciona o sistema até mesmo quando consegue ser "natural" [...] é esse natural que "funciona", que faz funcionar todo o resto. (LEJEUNE, 2014, p. 229, grifos do autor).

Essa "naturalidade" também pode ser percebida no "escritor múltiplo", denominação atribuída por Evelina Hoisel (2019) àqueles autores que "conjugam a criação literária, a atividade teórica, crítica e acadêmica", cuja presença prolifera-se no cenário cultural brasileiro a partir da segunda metade do século $X X$, tais como Silviano Santiago, Affonso Romano de Sant'Anna, Evandro Nascimento, Judith Grossman, dentre tantos outros. De acordo com Hoisel (2019, p. 103):

Em decorrência dos constantes trânsitos por diferentes lugares de fala, a ficção desses autores se constitui de uma mescla de escritas de procedências variadas, rompendo as fronteiras entre a literatura, teoria, crítica, discurso pedagógico, e também entre filosofia, história, sociologia etc., registrando a multiplicidade de suas atuações e de funções do sujeito inscrito em uma mesma malha textual, tornando-a indecidível nos seus contornos.

É a partir dessa prática, que Hoisel caracteriza as dramatizações e performances do escritor múltiplo como bioficções, as quais são construídas a partir do entrecruzamento dos discursos teórico, crítico e pedagógico desses escritores, perpassando as múltiplas alteridades de um sujeito "ao agregar, simultaneamente, a figura do teórico, do crítico, do docente, fazendo girar os seus saberes disseminando as suas microações" (2019, p. 104).

Nessa conjectura, a "atuação" do escritor em várias esferas significativas transforma-o em uma figura que exerce diversas atividades e funções, dentre as quais se destaca a diluição das fronteiras do que é literário, expandindo o campo da literatura para "fora de si" mesma em um movimento constante de renovação e questionamentos, não apenas acerca do fazer literário, mas de um fazer artístico que engloba, dentre tantos outros aspectos, aquilo que se desvanece no tempo, inclusive, aquilo que se reconfigura e reaparece forjado em velhos novos moldes, assim como o autor-artista ou o a(u)tor. 

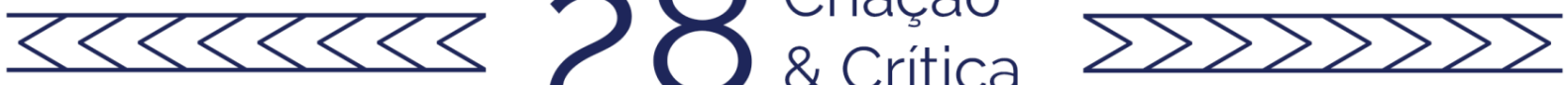

\section{Considerações finais}

A literatura contemporânea vivencia o transbordamento de seus limites, apresentando um espaço expansivo constantemente reformulado e ampliado. Essa literatura fora de si - expressão de Florencia Garramuño - é atravessada por múltiplas conexões, com práticas que evidenciam uma malha discursiva, cuja tessitura apresenta um questionamento da sua especificidade, ao exibir uma porosidade fronteiriça.

A partir desse campo estendido da literatura, cujas margens extrapolam a letra escrita ao trabalhar com signos que não delimitam seu pertencimento a um campo específico, seja ele arte, literatura, política ou algum outro, é possível observar a atuação do escritor performático, evidenciado na cena contemporânea.

Ao caminhar por diversos espaços narrativos, o autor contemporâneo utiliza o palco da linguagem para diluir as fronteiras que separam os discursos ficcionais, teóricos e midiáticos, expondo, além da espetacularização da escrita, os múltiplos modos de constituição de um sujeito.

Nesse local, há uma performance do autor, assim como em um espetáculo teatral, retomando o narrador tradicional postulado por Adorno, quando utiliza um "palco italiano" para representar a si mesmo. Enquanto nesse último, o ator separa-se da plateia pelo fosso da orquestra; no contemporâneo, o autor aproxima-se (e/ou separa-se) do público pela construção de uma figura do escritor - um a(u)tor com poses e máscaras previamente articuladas para a gestão de uma única marca: a daquele que escreve.

\section{Referências}

AGAMBEN, G. O autor como gesto. In.: Profanações. São Paulo: Boitempo, 2007.

AGUILAR, G.; CÁMARA, M. A máquina performática: a literatura no campo experimental. Trad. Gênese Andrade. Rio de Janeiro: Rocco, 2017.

ARFUCH, L. O espaço biográfico: dilemas da subjetividade contemporânea. Trad. Paloma Vidal. Rio de Janeiro: Ed. UERJ, 2010.

BAKHTIN, M. O autor e a personagem. In.: Estética da criação verbal. Trad. Paulo Bezerra. 4ed. São Paulo: Martins Fontes, 2003.

BARTHES, R. O rumor da língua. Prefácio Leyla Perrone-Moisés. Tradução de Mario Laranjeira. 2. ed. São Paulo: Martins Fontes, 2004.

BARTHES, R. O prazer do texto. São Paulo: Editora Perspectiva, 1987.

CARVALHEIRO, J. S. A concepção do autor em Bakhtin, Barthes e Foucault. In.: SIGNUM: estudos linguísticos, Londrina, n.11/2, p. 67-81, dez. 2008.

CHARTIER, R. O que é um autor? Revisão de uma genealogia. São Carlos: EdUFSCAR, 2014. 

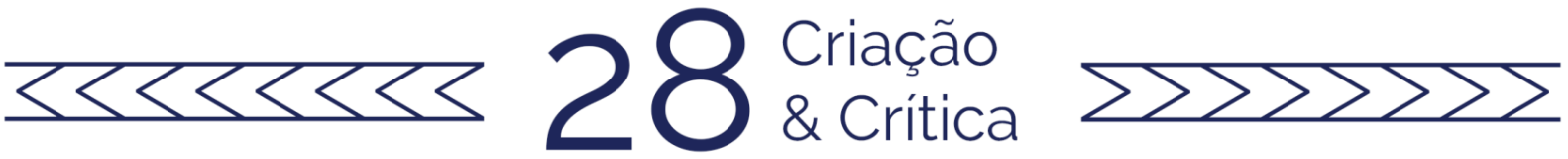

COLONNA, V. Tipologia da autoficção. In.: NORONHA, Jovita Maria Gerheim (Org.). Ensaios sobre a autoficção. Tradução: Jovita Maria Gerheim Noronha, Maria Inês Coimbra Guedes. Belo Horizonte: Editora UFMG, 2014.

COMPAGNON, A. O demônio da teoria: literatura e senso comum. 2. ed. Belo Horizonte: Editora UFMG, 2010.

DOUBROVSKY, S. O último eu. In.: NORONHA, Jovita Maria Gerheim (Org.). Ensaios sobre a autoficção. Tradução: Jovita Maria Gerheim Noronha, Maria Inês Coimbra Guedes. Belo Horizonte: Editora UFMG, 2014.

FOUCAULT, M. O que é um autor? Prefácio de José A. Bragança de Miranda e Antonio Fernando Cascais. Lisboa: Vega, 2002.

GASPARINI, P. Autoficção é o nome de que? In.: NORONHA, Jovita Maria Gerheim (Org.). Ensaios sobre a autoficção. Tradução: Jovita Maria Gerheim Noronha, Maria Inês Coimbra Guedes. Belo Horizonte: Editora UFMG, 2014.

HOISEL, E. Teoria, crítica e criação literária: o escritor e seus múltiplos. Rio de Janeiro: Civilização brasileira, 2019.

KLINGER, D. I. Escritas de si, escrita do outro: o retorno do autor e a virada etnográfica. Rio de Janeiro: 7 Letras, 2012.

LECARME, J. Autoficção: um mau gênero? In.: NORONHA, Jovita Maria Gerheim (Org.). Ensaios sobre a autoficção. Tradução: Jovita Maria Gerheim Noronha, Maria Inês Coimbra Guedes. Belo Horizonte: Editora UFMG, 2014.

LEUJENE, P. A imagem do autor na mídia. In.: NORONHA, J. M. G. (Org.) O pacto autobiográfico: De Rousseau à Internet. Tradução: Jovita Maria Gerheim Noronha, Maria Inês Coimbra Guedes. 2. ed. Belo Horizonte: Editora UFMG, 2014d.

SARLO, B. Tempo passado: cultura da memória e guinada subjetiva. Belo Horizonte: Editora UFMG, 2007.

SCHOLLHAMMER, K. E. Ficção brasileira contemporânea. 2. ed. Rio de Janeiro: Civilização Brasileira, 2011.

SIBILIA, P. O show do eu: a intimidade como espetáculo. 2 ed. Rio de Janeiro: Contraponto, 2016.

VIEGAS, A. C. O "retorno do autor" - relatos de e sobre escritores contemporâneos In: VALLADARES, Henriqueta Do Coutto Prado (Org.). Paisagens ficcionais: perspectivas entre o eu e o outro. Rio de Janeiro: 7Letras, 2007.

VILLAN, P. A prova do referencial. In.: NORONHA, Jovita Maria Gerheim (Org.). Ensaios sobre a autoficção. Tradução: Jovita Maria Gerheim Noronha, Maria Inês Coimbra Guedes. Belo Horizonte: Editora UFMG, 2014.

Recebido em: 24/07/2020

Aceito em: 02/11/2020

Referência eletrônica: DUAILIBE, Ane Beatriz dos Santos. Da morte à performace: o a(u)tor contemporâneo. Criação \& Crítica, n. 28, p., dez. 2020. Disponível em: <http://revistas.usp.br/criacaoecritica>. Acesso em: dd mmm. aaaa. 